\title{
Effects of Taking a Course Designed to Promote Learner Autonomy on English Language Teacher Candidates' Perceptions of Autonomous Learning
}

\author{
Ozgur Yildirim ${ }^{1}$ \\ ${ }^{1}$ Faculty of Education, Anadolu University, Eskisehir, Turkey \\ Correspondence: Ozgur Yildirim, Faculty of Education, Anadolu University, 26470, Eskisehir, Turkey. Tel: \\ 90-222-335-0580. E-mail: oyildirim@anadolu.edu.tr
}

Received: October 29, 2014

Accepted: November 10, 2014

Online Published: November 12, 2014

doi:10.5430/elr.v3n2p81

URL: http://dx.doi.org/10.5430/elr.v3n2p81

\begin{abstract}
The role of teachers and teacher education in the practice of promoting learner autonomy has been a focus of discussion in the field of second or foreign language education. However, although the importance of including the concept of learner autonomy into the language teacher education programs has been emphasized continuously, the studies that focus on the practical applications of the promotion of learner autonomy in teacher education are limited. The purpose of this paper is twofold: First, it introduces a course offered in the EFL (English as a Foreign Language) teacher education program of a state university in Turkey. This course was designed to promote learner autonomy for EFL teacher candidates and it has been offered for several years to the first-year students in the program. Second, it presents the results of a study conducted with 260 students who took the course. The study was designed to investigate the effects of taking the course on EFL teacher candidates' perceptions of learner autonomy. Findings of the study revealed that putting more emphasis on learner autonomy in English language teacher education may help future English teachers become better promoters of learner autonomy in their own classrooms.
\end{abstract}

Keywords: Learner autonomy, English teacher education, English teacher candidates

\section{Introduction}

Learner autonomy has been one of the key concepts in language instruction especially after the introduction of learner-centered approaches to language teaching contexts. Since communicative language teaching, learner-centeredness and learner autonomy emphasize the learner as the main factor in the learning process, many researchers have incorporated the idea of autonomy into their work (Benson, 2001). Cognitive and humanistic views of learning put a focus on the necessity to develop learner autonomy; here the main aim is to help students process information and become independent learners by using learning strategies, transfer their skills, and responsibility (Raya \& Fernandez, 2002). Teachers' attempts to introduce learner-centered approach to language classroom, their goal of helping learners to become independent, and their view that language learning requires the active involvement of learners are all connected to the notion of learner autonomy (Littlewood, 1996).

The role of teachers and teacher education in the practice of promoting learner autonomy has also been a focus of discussion in the field of second or foreign language education (Benson, 2001; Voller, 1997; Little, 1995; Crabbe, 1993). Little (1995) suggests that learner autonomy has been a matter for teacher education in two separate but related senses: (a) future teachers should be provided with the skills to develop autonomy in the learners that will be given into their charge, and (b) they should also be given a first-hand experience of learner autonomy in their training. However, although the importance of including the concept of learner autonomy into the language teacher education programs has been emphasized continuously, the studies that focus on the practical applications of the promotion of learner autonomy in teacher education are limited. This paper aims at making a contribution to the learner autonomy literature from the practical teacher education perspective. Thus, the purpose of this paper is two-fold: First, it introduces a course offered in the EFL (English as a Foreign Language) teacher education program of a state university in Turkey. This course was designed to promote learner autonomy for EFL teacher candidates and it has been offered for several years to the first-year students in the program. Second, it presents the results of a study conducted with 260 students who took the course. The study was designed to investigate the effects of taking the course on EFL teacher candidates' perceptions of learner autonomy. 


\section{Theoretical Framework}

The term learner autonomy has been defined in many different ways. In one of the earliest and the most quoted definitions, Holec (1981) defines learner autonomy as the ability to take charge of one's own learning. Holec's definition can be considered one of the origins of current debates on learner autonomy (Schmenk, 2005) but many other researchers elaborated that definition. Benson (2001) defines learner autonomy as the capacity to take control over, or responsibility for, one's own learning. This control or responsibility can take several forms based on different levels of the learning process. Benson and Voller (1997, p.1-2) suggested that the word 'autonomy' is used at least in five different ways in language education: for situations in which learners study entirely on their own, for a set of skills which can be learned and applied in self-directed learning, for an inborn capacity which is suppressed by institutional education, for the exercise of learners' responsibility for their own learning, and for the right of learners to determine the direction of their own learning. Benson (1997) also argues that current applied linguistics discourses have at least three versions of learner autonomy: in 'technical' version, learner autonomy is defined simply as an act of learning a language outside the framework of an educational institution and without the intervention of a teacher; in 'psychological' version, learner autonomy is defined as a capacity which allows learners to take more responsibility for their own learning; and in 'political' version, learner autonomy refers to the concept in terms of control over the processes and content of learning.

Understanding what autonomy is 'not' could also be helpful for interpreting what learner autonomy really means. Little (1991) and Benson (2001) summarized what 'autonomy is not' in language learning as follows: autonomy is not a synonym for self-instruction; that is, it is not limited to learning without a teacher; it does not require the teacher to give all the responsibility and control to the students; it is not just another language teaching method; it is not a single, easily described behavior; and it is not a state achieved by language learners.

Referring to the importance and desirability of learner autonomy, Kenny (1993) states that education takes place only when autonomy is being allowed to function because if autonomy is repressed or ignored then result is not education but some sort of conditioning procedure. Ellis and Sinclair (1989) suggest that helping learners become more autonomous can be beneficial because: learning can be more effective when learners take more control of it; and more responsible learners can take learning outside the classroom. Dickinson (1995) states that people who take the initiative in learning learn more and better than do people who rely on teachers only. Also, Lee (1998) points out that it is important to help students become aware of the benefits of independent learning so that they can learn continuously, even after completing their formal studies. In addition, listing the major characteristics of autonomous learners, researchers suggested that autonomous learners set learning goals, develop learning strategies and study plans, reflect on their own learning, work cooperatively, select relevant resources, are aware of the nature of learning, and assess their own progress (Benson, 2001; Chan, 2001; Breen \& Mann, 1997; Sheerin, 1997; Littlewood, 1996; Cotterall, 1995; Dickinson, 1993).

The definition, importance and desirability of learner autonomy, and the characteristics of autonomous learners suggest that fostering learner autonomy in the language learning contexts will improve the quality and standards of teaching and learning. In other words, considering all the aforementioned arguments on learner autonomy, it can be stated that by promoting learner autonomy in their classrooms, language teachers may be able to create more effective language learning environments for their students. An important way of helping language teachers promote learner autonomy in their classes is to make them familiar with the concept of learner autonomy during their teacher education process. Teacher candidates should be provided with the skills to develop autonomy in their future learners, and they should also experience learner autonomy themselves in their training (Little, 1995). Therefore, including a course on learner autonomy in the language teacher education curriculum can help teacher candidates understand and experience autonomy. In the rest of this paper, first, a course designed to promote learner autonomy for EFL teacher candidates will be introduced in detail; and then, the results of a study conducted to investigate the effects of the course on teacher candidates' perceptions of learner autonomy will be reported.

\section{The Course: Learner Autonomy}

The course named 'Learner Autonomy' has been offered in the EFL teacher education program of a state university in Turkey for five years. It is offered in the first year, second semester, of the program as a compulsory course. The instructor and the students meet for three-hours a week for twelve weeks. The goal of the course has been identified as follows: to develop an autonomous learner who is able to define the basic concepts and skills of autonomous learning, apply these concepts and skills into appropriate contexts, use learning strategies, and be open to lifelong learning. 
The learning outcomes of the course are stated as follows:

At the end of this course, the student will be able to;

1. define the basic concepts and skills of autonomous learning

a. explain the concept of autonomous learning and the features of autonomous learning

b. define note-taking strategies

c. list and define learning styles and strategies

d. explain learning anxiety and find out the ways to cope with it

e. define motivation and its types

2. use autonomous learning concepts and skills to become an autonomous learner

a. schedule his time effectively

b. find out ways to cope with demotivation and high-anxiety and applies them

c. use the appropriate learning styles and strategies to make the learning process easier

3. gain skills of solowork and groupwork

a. schedule for solowork and groupwork

b. evaluate the efficiency of solowork and groupwork by questioning, criticizing and comparing

4. make reflection and self-evaluation related to his own learning process by using analytical and critical thinking

a. analyze his own learning skills to change and correct the weak ones and develop comparatively weaker ones

b. realize the effectively used learning skills and adapt them to new learning situations

c. construct his own lifelong learning by realizing his learning strengths and weaknesses

In general, the content of the course includes topics like general information about learner autonomy, note-taking skills, presentation skills, raising awareness about learning and the learner, learning styles, learning strategies, brain dominance, memory and neuro-linguistic programming, anxiety and the ways of coping with it, understanding instructions, managing time, motivation, collaborative learning, reflective learning, and self-evaluation.

Materials and techniques used in the course include informative articles about the definition of and misconceptions about learner autonomy, self-exploratory questionnaires, self-exploratory checklists, small-group in-class tasks (e.g. filling-in charts, tables, diagrams), small-group assignments, individual self-exploratory assignments, and presentation assignments. Students do not follow a specific book in this course but at the beginning of the semester they are given a course-pack which includes articles, questionnaires, checklists, charts, tables, diagrams, etc. Throughout the semester students sometimes read articles and discuss them in the lesson under the supervision of the instructor, they sometimes make presentations, or sometimes they engage in small-group or individual activities for the self-exploration of their learner characteristics, individual differences, etc. The two important books in the reading list of the course are Burns and Sinfield (2003) and Cottrell (1999).

The main aim of the study reported in this paper was to investigate whether taking the course 'Learner Autonomy' changed students perceptions related to learner autonomy. The two research questions that guided the design and implementation of the study were as follows:

1. Does taking the course 'Learner Autonomy' change students' perceptions of learner responsibilities in the language learning process? If yes, in what areas does the change happen?

2. Does taking the course 'Learner Autonomy' change students' perceptions related to learner abilities to act autonomously? If yes, in what areas does the change happen?

\section{Methodology}

\subsection{Participants and Setting}

The participants of this study were 260 (164 females, 96 males, age 17-20) first-year students studying in an EFL teacher education program of a state university in Turkey. They had been placed in this program by the Turkish 
Student Selection and Placement Center according to their scores from the national university entrance exam. As the students were placed in the program as a result of a national exam, there were participants from all geographical regions of Turkey in this study.

The first year of this four-year teacher education program focuses on sharpening students' English language skills by offering courses such as Contextual Grammar, Oral Communication Skills, Academic Reading, Critical Reading, Written Communication, Academic Writing and Report Writing, and Listening Comprehension and Note Taking. Apart from these courses which focus on English language skills and areas, the students of the program take the course 'Learner Autonomy' during the second semester of the program, the details of this course has been presented in the previous section of this paper. In the remaining three years of the program the students take various theoretical and applied courses on teaching English as a foreign language. Most of the graduates of the program work as EFL teachers in public and private schools and universities in Turkey.

\subsection{Instrument}

Investigating learner autonomy is not an easy task since the students' perceptions related to this concept cannot be directly observed or gauged (Reinders, 2000; Benson, 2001). Researchers suggest that focusing on language learners' perceptions of learner and teacher responsibilities in the language learning process, and their perceptions of language learners' abilities to act autonomously can be helpful for understanding their perceptions related to learner autonomy (Chan, 2003; Spratt, Humphreys \& Chan, 2002; Chan, Spratt \& Humpreys, 2002; Benson, 2001, Chan, 2001; Reinders, 2000; Victori \& Lockhart, 1995).

The instrument used in this study was adapted from a questionnaire developed by Chan, Spratt and Humpreys (2002) to investigate language learners' readiness for learner autonomy. The adapted questionnaire focused on investigating language learners' perceptions related to learner autonomy by asking questions in two sections about the participants' perceptions of learner responsibilities in the language learning process, and their perceptions of learner abilities to act autonomously. Section 1 of the questionnaire focused on learner responsibilities and contained 13 questions about how much responsibility language learners have in different aspects of the language learning process such as making sure students make progress during lessons, identifying their weakness in English, evaluating their learning, or deciding what they learn outside class. The participants answered the questions on a five-point scale: (1) not at all, (2) a little, (3) some, (4) mainly, (5) completely. Section 2 of the questionnaire focused on learner abilities and asked 11 questions to the participants about how they evaluate language learners' abilities to act autonomously in different situations such as choosing learning activities, choosing learning materials, choosing learning objectives, or evaluating the course. The participants answered the questions on a five-point scale: (1) very poor, (2) poor, (3) OK, (4) good, (5) very good.

Expert opinion was taken for ensuring the validity of the adapted questionnaire for the research context. The experts were university professors in the field of foreign language teacher education and they were all familiar with the research context. For internal reliability, Cronbach's alpha was calculated and found to be .82 for the first administration, and .87 for the second administration.

\subsection{Data Collection and Analysis Procedure}

The data of the study were collected in 2012-2013 and 2013-2014 academic years. The questionnaire was given to the participants at the beginning and at the end of the second semester of each academic year. In other words, the participants were given the questionnaire before and after they took the course 'Learner Autonomy'.

In order to see the effect of taking the course on the participants' perceptions related to learner autonomy, for each item in the questionnaire the mean score from each administration was found and then significance of the mean score differences were calculated by using paired-samples t-tests (two-tailed). As there were 24 items in the questionnaire, 24 different paired-samples t-test calculations were made. In order to address the possible risk of making a Type I error, Bonferroni adjustment technique was used and the significance value for each t-test was taken as $.002(.05 / 24)$.

\section{Results and Discussion}

\subsection{Change in Perceptions of Student Responsibilities}

The first research question of the study was about the change in participants' perceptions of student responsibilities in the language learning process. Table 1 shows the mean scores for the items from the first section of the questionnaire. 
Table 1. Comparison of mean scores of responsibility items before and after taking the course

\begin{tabular}{|c|c|c|c|c|c|c|}
\hline \multirow[t]{2}{*}{ How much responsibility do students have in ... } & \multicolumn{2}{|c|}{ Before the Course } & \multicolumn{2}{|c|}{ After the Course } & \multirow[b]{2}{*}{$d f$} & \multirow[b]{2}{*}{$t$} \\
\hline & Mean & SD & Mean & $\mathrm{SD}$ & & \\
\hline $\begin{array}{l}\text { 1. making sure they make progress during } \\
\text { lessons? }\end{array}$ & 2.44 & 1.42 & 3.98 & 1.14 & 259 & $-14.23^{*}$ \\
\hline $\begin{array}{l}\text { 2. making sure they make progress outside } \\
\text { class? }\end{array}$ & 2.95 & 1.27 & 4.12 & 0.92 & 259 & $-12.36^{*}$ \\
\hline $\begin{array}{l}\text { 3. stimulating their interests in learning } \\
\text { English? }\end{array}$ & 2.80 & 1.51 & 3.88 & 1.06 & 259 & $-9.47^{*}$ \\
\hline 4. identifying their weaknesses in English? & 1.99 & 1.18 & 3.90 & 1.00 & 259 & $-20.18^{*}$ \\
\hline 5. making them work harder? & 2.94 & 1.16 & 4.13 & 1.02 & 259 & $-12.74^{*}$ \\
\hline $\begin{array}{l}\text { 6. deciding the objectives of their English } \\
\text { classes? }\end{array}$ & 2.68 & 1.41 & 2.85 & 1.44 & 259 & -1.41 \\
\hline $\begin{array}{l}\text { 7. deciding what they should learn next in their } \\
\text { English lessons? }\end{array}$ & 2.55 & 1.40 & 2.95 & 1.44 & 259 & -2.94 \\
\hline $\begin{array}{l}\text { 8. choosing what activities to use to learn } \\
\text { English in their English lessons? }\end{array}$ & 2.40 & 1.37 & 2.75 & 1.44 & 259 & -2.84 \\
\hline 9. deciding how long to spend on each activity? & 2.51 & 1.36 & 3.60 & 0.96 & 259 & $-11.22^{*}$ \\
\hline $\begin{array}{l}\text { 10. choosing what materials to use to learn } \\
\text { English in their English lessons? }\end{array}$ & 2.63 & 1.29 & 4.02 & 1.00 & 259 & $-13.63^{*}$ \\
\hline 11. evaluating their own learning? & 2.55 & 1.35 & 3.61 & 1.02 & 259 & $-10.31^{*}$ \\
\hline 12. evaluating the course? & 2.39 & 1.34 & 3.70 & 0.99 & 259 & $-12.72^{*}$ \\
\hline $\begin{array}{l}\text { 13. deciding what they should learn outside } \\
\text { class? }\end{array}$ & 2.78 & 1.17 & 4.15 & 0.91 & 259 & $-15.10^{*}$ \\
\hline
\end{tabular}

* significant at the Bonferroni adjusted significance level of .002

As Table 1 indicates, there was a significant increase in the mean scores of ten items. In other words, in ten out of 13 items, the participants' perceptions of learner responsibilities changed significantly in a positive way between before and after taking the course.

The first significant change was in the item which was about making sure students make progress during lessons. According to this result, before taking the course 'Learner Autonomy', the participants felt that language learners have less responsibility about making progress in an English lesson, and they most probably gave that responsibility to the teachers. However, after taking the course, they started to feel that learners have more responsibility in terms of ensuring progress during lessons. A significant change was also seen in the item about making progress outside class. All in all, it can be suggested that taking a course on learner autonomy changed EFL teacher candidates' perceptions about the learner responsibilities of ensuring progress in or outside class. Apart from making progress, another significant change was detected in stimulating students' interest in learning English. In other words, according to the results of the study, after taking the course, teacher candidates started to put more responsibility on students in terms of stimulating their interests in learning English.

Identifying weaknesses in learning English was another aspect of language learning about which the participants' responsibility perception changed significantly in a positive way. Also, there was a significant increase in the mean score of the item related to making students work harder. These results suggest that before taking the course 'Learner Autonomy' the participants were putting less responsibility on the learner in terms of identifying their weaknesses in English and making them work harder, but they started to put more of those responsibilities on the learner after taking the course.

Deciding how long to spend on each activity and choosing what materials to use to learn English were two other items whose mean scores increased significantly. These significant increases can be considered interesting because 
making a decision about the time spent on classroom activities and choosing learning materials are generally professional decisions made by teachers as a result of their training and experience, but after taking the course 'Learner Autonomy' the participants of the current study indicated that they were ready for giving more responsibility to learners on these aspects of learning.

There were two items related to evaluation in the first section of the questionnaire. One of these items was about students' evaluation of their own learning and the other one was about the evaluation of the English course taken. The mean scores of both items increased significantly after taking the course 'Learner Autonomy'. The significant mean increase in the first evaluation-related item indicates that after taking the course teacher candidates were ready to give more self-evaluation responsibility to learners. The increase in the mean score of the second item suggests that taking a course on learner autonomy makes teacher candidates feel that language learners have more responsibility in evaluating the effectiveness of an English lesson. All in all, it can be concluded that taking a course related to learner autonomy affects language learners' perceptions on student responsibilities of the evaluation of learning and of the English lesson.

Another significant mean score increase was seen in the item related to deciding what to learn outside class. This increase indicates that after taking a course on learner autonomy language teacher candidates feel that language learners should have more responsibility related to outside class learning as well.

The mean scores of three items in the first section of the questionnaire did not increase significantly. A closer look at these items show that all of the items were related to professional decisions made by the teachers. That is, these items were about deciding the objectives of the English lesson, deciding what students should learn next in their English lessons, and choosing activities to use in English lessons. The mean scores of all these three items were under 3,0 before taking the course 'Learner Autonomy' and they did not increase significantly after taking it. These results may indicate that even after taking a course on learner autonomy, the language teacher candidates still think that the teacher holds the main responsibility in those aspects of the language learning process.

\subsection{Change in Perceptions of Student Abilities}

The second research question of the study was about the change in participants' perceptions of langue learners' abilities to act autonomously. The second section of the questionnaire was related to this research question and Table 2 presents the mean scores for the items from that section.

Table 2. Comparison of mean scores of ability items before and after taking the course

\begin{tabular}{lccccccc}
\hline \multirow{2}{*}{$\begin{array}{l}\text { How do you evaluate language learners' } \\
\text { abilities to ... }\end{array}$} & \multicolumn{2}{l}{ Before the Course } & \multicolumn{2}{c}{ After the Course } & & \\
\cline { 2 - 5 } & Mean & SD & Mean & SD & & df & \multicolumn{1}{c}{$t$} \\
\cline { 2 - 6 } 1. choose learning activities in class? & 2.70 & 1.22 & 3.91 & 0.99 & 259 & $-12.68^{*}$ \\
2. choose learning activities outside class? & 3.05 & 1.19 & 4.04 & 0.89 & 259 & $-10.67^{*}$ \\
3. choose learning objectives in class? & 2.76 & 1.47 & 3.01 & 1.49 & 259 & -1.84 \\
4. choose learning objectives outside class? & 3.71 & 1.38 & 3.95 & 1.25 & 259 & -2.09 \\
5. choose learning materials in class? & 2.78 & 1.49 & 2.95 & 1.52 & 259 & -1.21 \\
6. choose learning materials outside class? & 3.01 & 1.17 & 4.30 & 0.80 & 259 & $-14.11^{*}$ \\
7. evaluate their own learning? & 2.68 & 1.41 & 3.76 & 0.97 & 259 & $-10.00^{*}$ \\
8. evaluate the course? & 2.49 & 1.39 & 3.83 & 0.85 & 259 & $-12.83^{*}$ \\
9. identify their weaknesses in English? & 2.65 & 1.27 & 4.08 & 0.79 & 259 & $-15.82^{*}$ \\
10. decide what they should learn next in their & 2.48 & 1.54 & 2.75 & 1.43 & 259 & -1.99 \\
English lessons? & & & & & & \\
11. decide how long to spend on each activity? & 2.66 & 1.54 & 2.92 & 1.45 & 259 & -1.96 \\
\hline
\end{tabular}

* significant at the Bonferroni adjusted significance level of .002

The first two items in the second section of the questionnaire were about language learners' abilities to choose learning activities in and outside class. The mean scores for these two items increased significantly after the participants took the course 'Learner Autonomy'. These results indicate that after taking a course on learner autonomy, language teacher candidates started to have more positive perceptions related to language learners' 
abilities to choose learning activities in and outside class. Another significant increase was seen in the item related to choosing learning materials outside class. This increase indicates that after taking a course on learner autonomy, future language teachers' perceptions related to language learners' abilities of out-of-class material selection have improved.

As it was the case in the responsibilities section of the questionnaire, in the abilities section of the questionnaire the mean scores of the two items related to evaluation increased significantly. The significant mean score increase in the item related to language learners' abilities to evaluate their own learning was 1.08; and the increase in the item related to the evaluation of the English course taken was 1.33. These two results show that after taking a course on learner autonomy, future language teachers have improved their perceptions related to language learners' abilities to evaluate their own learning and the language course they are taking. In addition to evaluation, the mean score of the item related to language learners' abilities to identify their weaknesses in English also increased significantly after taking the course. This significant increase means that the course improved the participants perceptions related to language learners' abilities to identify their own weaknesses.

A closer look at the items whose mean scores did not change significantly in the second section of the questionnaire shows that all those items are related to professional decisions made by teachers (choosing learning objectives in and outside class, choosing learning materials in class, deciding what to learn next, and deciding how long to spend on each activity), as it was the case in the first section of the questionnaire.

\section{Conclusion}

The results of this study indicate that taking a course on learner autonomy makes positive changes on EFL teacher candidates' perceptions related to learner autonomy in many aspects of learning. After taking the course named 'Learner Autonomy', the participants of the study started to give more responsibility than before to language learners in the following aspects of learning: making sure they make progress during English lessons, making sure they make progress outside class, stimulating their interests in learning English, identifying their weaknesses in English, making them work harder, deciding how long to spend on each activity, evaluating learning, and evaluating the English course.

In addition, after taking the course, the participants of the study started to think that language learners have better abilities in the following aspects of learning: choosing learning activities in class, choosing learning activities outside class, choosing learning materials outside class, evaluating their own learning, evaluating the course, identifying their weaknesses in English, and deciding what they should learn next in their English lessons.

Teacher-based approaches to the promotion of learner autonomy were noted by Benson (2001) as one of six approaches to the development of learner autonomy. Such approaches to promoting autonomous learning focus on teacher's role on giving more control to language learners in two aspects: the role of teacher education and the role of teachers.

Emphasizing the dependence of learner autonomy on teacher autonomy, Little (1995) states that "genuinely successful teachers have always been autonomous in the sense of having a strong sense of personal responsibility for their teaching, exercising via continuous reflection and analysis the highest possible degree of affective and cognitive control of the teaching process, and exploiting the freedom that this confers (p. 179)."

Little (1995) also suggests that future teachers of English can be provided with some information related to importance and fostering of learner autonomy, but that would not be enough unless they are provided with the opportunities of feeling learner autonomy themselves in their own learning process. Little states that "language learners are more likely to operate as independent flexible users of their target language if their classroom experience has already pushed them in this direction, by the same token, language teachers are more likely to succeed in promoting learner autonomy if their own education has encouraged them to be autonomous (p. 180)."

The results of this study show that adding a course on learner autonomy in the curriculum of a language teacher education program may make the positive effects of experiencing learner autonomy as Little (1995) argues. In addition, taking such a course may help future language teachers carry the basic teacher roles in autonomous learning that Voller (1997) suggests. Voller gives three basic teacher roles in autonomous learning: facilitator, in which teacher provides support for learning; counselor, in which there is one-to-one interaction with the learner; and resource, in which teacher is the source of knowledge and expertise. Features of these roles are discussed under two headings: technical support and psycho-social support. 
The psycho-social features are:

- the personal qualities of the facilitator (being caring, supportive, patient, tolerant, emphatic, open, non-judgmental);

- a capacity for motivating learners (encouraging commitment, dispersing uncertainty, helping learners to overcome obstacles, being prepared to enter into a dialog with learners, avoiding manipulating, objectifying or interfering with, in other words, controlling them);

- an ability to raise learners' awareness (to 'decondition' them from preconceptions about learner and teacher roles, to help them perceive the utility of, or necessity for, independent learning).

Features related to technical support are:

- helping learners plan and carry out their independent language learning by means of needs analysis ( both learning and language needs), objective setting (both short and longer term, achievable), work planning, selecting materials, and organizing interactions;

- helping learners evaluate themselves (assessing initial proficiency, monitoring progress, and self and peer-assessment);

- helping learners acquire the skills and knowledge needed to implement the above (by raising their awareness of language and learning, by providing learner training to help them identify learning styles and appropriate strategies) (p.102).

Consequently, the results of the current study suggest that making learner autonomy more than a concept covered only in methodology courses, helping students have more practical and first-hand exposure of learner autonomy, and giving learner autonomy a place in the language teacher education curriculum may help future language teachers become better promoters of learner autonomy in their own classrooms. Little (1995) states that learner autonomy and teacher autonomy are interdependent concepts, and therefore, the promotion of learner autonomy depends on the promotion of teacher autonomy; "if we are to achieve large-scale progress in the promotion of learner autonomy we must now bring our focus of concern back to the teacher, and especially to the way in which we organize and mediate teacher education (p.181)."

\section{References}

Benson, P. \& Voller, P. (Eds.) (1997). Autonomy and Independence in Language Learning. London: Longman.

Benson, P. (2001). Teaching and Researching Autonomy in Language Learning. London: Longman.

Breen, M.P. \& Mann, S. (1997). Shooting arrows at the sun: perspectives on a pedagogy for autonomy. In Benson P. \& Voller P. (Eds.) Autonomy and Independence in Language Learning (pp. 132-149). London: Longman.

Burns, T. \& Sinfield, S. (2003). Essential study skills: The complete guide to success @ university. London: Sage Publications.

Chan, V. (2001). Readiness for learner autonomy: what do our learners tell us?. Teaching in Higher Education, 6 (4), 505-518. http://dx.doi.org/10.1080/13562510120078045

Chan, V. (2003). Autonomous Language Learning: the teachers' perspectives. Teaching in Higher Education, 8 (1), 33-54. http://dx.doi.org/10.1080/1356251032000052311

Chan, V., Spratt, M. \& Humphreys, G. (2002). Autonomous language learning: Hong Kong tertiary students' attitudes and behaviors. Evaluation and Research in Education, 16 (1), 1-18. http://dx.doi.org/10.1080/09500790208667003

Cotterall, S. (1995). Readiness for autonomy: investigating learner beliefs. System, 23 (2), 195-206. http://dx.doi.org/10.1016/0346-251X(95)00008-8

Cottrell, S. (1999). The study skills handbook. London: Macmillan Press Ltd.

Crabbe, D. (1993). Fostering autonomy from within the classroom: the teacher's responsibility. System, 21 (4), 443-452. http://dx.doi.org/10.1016/0346-251X(93)90056-M

Dickinson, L. (1993). Talking shop: aspects of autonomous learning: An interview with Leslie Dickinson. ELT Journal, 47 (4), 330-336. http://dx.doi.org/10.1093/elt/47.4.330 
Dickinson, L. (1995). Autonomy and motivation: a literature review. System, 23 (2), 165-174. http://dx.doi.org/10.1016/0346-251X(95)00005-5

Ellis, G. \& Sinclair, B. (1989). Learning to learn English. Cambridge: Cambridge University Press.

Esch, E. (1997). Learner training for autonomous language learning. In Benson P. \& Voller P. (Eds.) Autonomy and Independence in Language Learning (pp. 164-176). London: Longman.

Holec, H. (1981). Autonomy in Foreign Language Learning. Oxford: Pergamon.

Kenny, B. (1993). For More Autonomy. System, 21 (4), 431-442. http://dx.doi.org/10.1016/0346-251X(93)90055-L

Lee, I. (1998). Supporting greater autonomy in language learning. ELT Journal, 52 (4), 282-289. http://dx.doi.org/10.1093/elt/52.4.282

Little, D. (1991). Learner Autonomy. 1: Definitions, Issues and Problems. Dublin: Authentik.

Little, D. (1995). Learning as dialogue: the dependence of learner autonomy on teacher autonomy. System, 23 (2), 175-181. http://dx.doi.org/10.1016/0346-251X(95)00006-6

Littlewood, W. (1996). Autonomy: an anatomy and a framework. System, 24 (4), 427-435. http://dx.doi.org/10.1016/S0346-251X(96)00039-5

Raya, M. J. \& Fernandez, M. P. (2002). Learner autonomy and new technologies. Educational Media International, 39, 60-68. http://dx.doi.org/10.1080/09523980210131240

Reinders, H. W. (2000). Do It Yourself. A Learners' Perspective on Learner Autonomy and Self-Access Language Learning in an English Proficiency Program. M.A. Thesis Submitted to Groningen University. Available at www.hayo.nl.

Schmenk, B. (2005). Globalizing Learner Autonomy. TESOL Quarterly, 39, 107-118. http://dx.doi.org/10.2307/3588454

Sheerin, S. (1997). An exploration of the relationship between self-access and independent learning. In Benson P. \& Voller P. (Eds.) Autonomy and Independence in Language Learning (pp. 54-65). London: Longman.

Spratt, M., Humphreys, G. \& Chan, V. (2002). Autonomy and motivation: which comes first?. Language Teaching Research, 6 (3), 245-266. http://dx.doi.org/10.1191/1362168802/r106oa

Victori, M. \& Lockart, W. (1995). Enhancing metacognition in self-directed learning. System, 23 (2), 223-234. http://dx.doi.org/10.1016/0346-251X(95)00010-H

Voller, P. (1997). Does the Teacher Have a Role in Autonomous Language Learning?. In Benson P. \& Voller P. (Eds.) Autonomy and Independence in Language Learning (pp. 98-113). London: Longman. 